\title{
Addressing CLIL Lecturers' Needs: Reflections on Specific Methodological Training
}

\author{
Candela Contero \\ FRANCISCO ZAYAS \\ Universidad de Cádiz \\ José LUIS ARCO TIRADO \\ Universidad de Granada
}

Received: 24 ${ }^{\text {th }}$ October $2017 /$ Accepted: 20 ${ }^{\text {th }}$ March 2018

ISSN: 1697-7467

\begin{abstract}
Following the launch of the project 'Analysis and quality assurance of plurilingual Higher Education programmes in Andalusia', diverse voices have been warning, irrespective of specific linguistic problems, about the difficulties university teachers might have in implementing a CLIL approach in the classroom. This study delves into the nature of the problem whilst studying the extent to which CLIL lecturers in different Andalusian public universities are aware of potential hurdles. The observational study intends to identify lecturers' perceptions on their teaching skills when delivering CLIL lessons. The rapid expansion of Integrating Content and Language in Higher Education institutions requires more research into the key additional teaching skills needed in order to deliver high quality instruction. The sample consists of 138 lecturers belonging to 66 different fields of knowledge, distributed across six public universities in the Spanish region of Andalusia. A 15-item survey was designed and implemented online in the academic year of 2016/2017. The results allow us to identify methodological shortcomings among Andalusian CLIL lecturers. This analysis contributes to design a specific programme for didactic training addressed to CLIL university teachers.
\end{abstract}

Keywords: Content and Language Integrated Learning (CLIL), Integrating Content and Language in Higher Education (ICLHE), Bilingual education, Methodology, Teacher Training.

Hacia las necesidades de los docentes universitarios AICLE. Aproximaciones a una formación metodológica específica.

RESUMEN: Desde la puesta en marcha del proyecto 'Análisis y Garantía de Calidad de la Educación Plurilingüe en la Educación Superior en Andalucía' han sido diversas las voces que, con independencia de los problemas de carácter lingüístico, advierten sobre las dificultades en la aplicación de la modalidad AICLE para los docentes universitarios. Este estudio abunda en la naturaleza de dicha problemática y revisa la medida en que el profesorado AICLE de las diferentes universidades públicas andaluzas es consciente de ello. Este estudio trata de identificar la percepción de los profesores universitarios sobre sus habilidades en su docencia AICLE. La expansión de integración de contenido y lengua en las instituciones de educación superior exige más investigación sobre las habilidades didácticas requeridas para la docencia AICLE. La muestra consistió en 138 profesores de 66 áreas de conocimiento diferentes pertenecientes a 6 universidades públicas de la región española de Andalucía. Para 
ello, se diseñó una encuesta en línea con un total de 15 ítems que lanzó en el curso académico de 2016/2017. Los resultados nos permiten identificar las carencias metodológicas de los profesores AICLE en las universidades andaluzas. Este análisis nos ayuda en el diseño de un programa específico de formación didáctica para docentes AICLE en Educación Superior.

Palabras clave: Aprendizaje Integrado de Contenidos y Lenguas (AICLE), Integración de Contenidos y Lenguas en Educación Superior (ICLHE), Educación bilingüe, Metodología, Formación del profesorado.

\section{INTRODUCTION}

On the global stage, as universities increasingly embrace globalization, the service provided to students is in constant evolution. Most Andalusian universities are trying to integrate foreign languages (FL) into their teaching in order to improve local students' career prospects, encourage mobility and attract potential incoming students. The importance given to designing bilingual and plurilingual programmes in Higher Education institutions (Doiz, Lasagabaster \& Sierra, 2013) has increased across Spain. A recent example of the trend towards integrating a foreign language into content teaching is the Conference of Rectors of Spanish Universities (CRUE) agreement. This association has recently published guidelines for linguistic policies and the internationalization of Spanish universities. The text aims to intensify the promotion of plurilingualism and facilitate, among other initiatives (such as the improvement of FL competences among university personnel), the teaching of subjects in different languages (CRUE, 2017).

Within this context, the implementation of effective plurilingual education models is an on-going empirical process which is not without challenges at scientific, institutional and policy levels (Arco-Tirado et al. 2018). In the process of extending plurilingual programmes in Andalusian universities, teachers and researchers face a number of challenges and difficulties when dealing with methodological teaching characteristics tied to the integration of content and foreign language (CLIL). (We use the term CLIL, but see the introduction to this volume, for a brief discussion of terminology). In addition to linguistic strategies related to the integration of an L2, as suggested by Mehisto et al. (2008: 105-109), Pavón \& Gaustad (2013: 87) state that:

Bilingual training courses must address methodological issues relevant to this type of teaching such as task-based learning, class management [...], assessment criteria and tools, collaborative learning, techniques to enhance teacher-student and student-student interaction, criteria for selecting academic content, structuring bilingual lessons, attention to heterogeneous classes, independent learning, designing activities and searching for course materials, use of multimedia and on-line resources (webquests, podcasts, browsing, etc.).

These specific methodological issues in the field of Integrating Content and Language in Higher Education (ICLHE) were already noted by Zayas \& Contero (2012) and by Pérez Cañado (2013). Perez Cañado suggested that, with or without previous didactic knowledge, and whatever their trajectory, lecturers appear to be aware of the importance of linguistic 
competence. We would suggest that bilingual teaching techniques are equally important. More recently, Contero (2017) used observational data to find that 259 (pre- or in-service) university CLIL teachers agreed that their lack of specific training in bilingual teaching eventually impacted on the functioning of Content and Language Integrated Learning at university level. Other researchers like Ellison et al. (2017: 73) found that university teachers with no specific knowledge about methodological requirements for teaching in a FL, tend to prioritise linguistic problems. Their teaching experience in L1 seems to be used as an endorsement of their methodological capabilities. In fact, research has found that the transition from L1 monolingual teaching to CLIL teaching tends to be interpreted by teachers as a process of translation rather than adaptation. This is suggested in Contero's findings (2017) which suggest that some of the methodological problems derived from the use of a FL could be linked to the fact that CLIL didactic materials are translated rather than adapted. Bilingual teaching requires specific methodological treatment and, with it, distinct training, independent from any help with language (Järvinen, 2009).

Our study indicates that lecturers may not always be aware of methodological shortcomings for CLIL teaching. This appears to vary depending on the discipline, a circumstance which can be perceived as the population of lecturers who put CLIL into practice effectively in the field of didactics is much smaller than in the faculties of business, economics, engineering, etc., even when most of the time these could be interpreted as EMI (Smit \& Dafouz, 2012). However, despite the purely experimental nature of CLIL teacher development in many educational degrees (Romero \& Zayas, 2017: 215-225), the perception of didactic specialists on the methodological needs for CLIL university teaching can be doubly valuable.

This paper is hence aimed at identifying key methodological and/or linguistic needs in plurilingual programmes in Andalusian universities. The research questions which guide the study were: What is the typical professional profile of a plurilingual university teacher? Which scientific fields use this way of teaching the most? Are methodological intricacies clearly identified by lecturers along with linguistic ones? Are teaching styles affected by methodological and/or linguistic variables? And if so, what are these variables and to what extent do they affect university CLIL teaching styles?

This research could contribute to pave the way for CLIL development for university teachers focused on their specific methodological needs, whilst sufficiently differentiating them from the methodological needs of secondary school teachers and other educational levels (Cenoz \& Etxague, 2013).

\section{Methodology}

\subsection{Data-gathering}

The sampling selection was based on a non-probabilistic sampling technique called "purposeful sampling" (Martínez, 1995), and involved the following actions: (a) deciding the eligibility criteria (i.e., lecturer with any kind of contractual relationship with a public Andalusian university, teaching subjects which were not directly related to linguistics), (b) providing the resources necessary to reach out to participants (e.g., email communication with participants on the AGCEPESA project, website fully reliable and accessible by invitation 
only, hosting the questionnaire and gathering the data in an Excel file after completion by each participant), and (c) determining the methods of participant selection (i.e., self-selection based on interest in collaborating with the study).

\subsection{Instruments}

The study included the design of a questionnaire on teacher perceptions regarding the methodological skills needed by CLIL lecturers. It consisted of 15 items, grouped into three sections (see Table 1, below). The first gathered demographic information from the participants, their field of knowledge, years of experience teaching CLIL as well as other items related to their CLIL teaching practice. The second focused on describing their didactic style and included two parts with three questions in each, (i.e., six questions). The third focused on self-assessment of the quality and impact of their teaching style on students' learning and acquisition of professional competencies. In parts two and three the questionnaire measured the respondents' level of conformity with the statements provided by means of a Likert scale which ranged from total agreement to total disagreement.

\subsection{Procedure}

Questionnaire design implied three stages. The first involved reviewing bibliographical references and survey models for CLIL university teachers in recent methodological research (e.g. Contero 2017; Ellison et al. 2017; Papaja, 2011; Pavesi et al. 2001). We felt that one of the most important contributions to studying methodological problems in CLIL was the work of Pavesi et al. (2001). Their research had contributed significantly to questionnaires designed by Contero (2017) and Estrada (2017), (even though the latter focuses more specifically on methodological strategies for lecturers in correcting errors in oral production (both in monolingual (i.e. Spanish) and in CLIL teaching)) ${ }^{1}$.

Contero (2017), using both a survey and a classroom observation rubric as data collection tools, identified eight 'problems' which might impede successful CLIL teaching at university level:

- Problem 1: 57\% of CLIL sessions observed did not include teacher-student interaction.

- Problem 2: 98\% of respondents confessed that students never participated more than lecturers and $31 \%$ even rejected the possibility of systematic open participation by students.

- Problem 3: 60\% of didactic materials used by CLIL lecturers were merely informative.

1 The study of Estrada (2017), like that of Contero (2017), is based on data analysis, obtained through direct observation of university teaching in a foreign language, as well as the 118 surveys that university teachers answered. The objective of this study is not, in the first instance, to identify methodological problems, but rather to identify specific aspects of behaviour in so-called linguistic related episodes (LRE), both in the field of LE teaching and also in CLIL teaching (64 of the 118 surveys received refer to CLIL university teaching). However, 4 out of the 12 questions for university teachers relate to their roles as evaluators, an issue closely linked with methodology and, in a broad sense, beliefs. 
- $\quad$ Problem 4: 91\% of teaching-learning processes took place solely within the classroom and $45 \%$ did not even consider using dynamic learning activities. Furthermore, $94 \%$ of teaching experiences observed did not show any time control over tasks and $79 \%$ of these tasks offered no continuity or link to each other.

- Problem 5: 51\% of teaching moments observed had not considered the need to motivate students.

- Problem 6: More than $90 \%$ of teaching did not provoke students with humorous or (non-insulting) references to personal attitudes, political affiliation and religious beliefs or ethics.

- Problem 7: 65\% of tasks provided during CLIL teaching moments did not match the previous linguistic input and over $60 \%$ of basic CALP vocabulary had not been analysed.

- Problem 8: 64\% of potential CLIL teachers said they would design their didactic materials using mere translation of those employed for regular L1 teaching.

Reviewing these findings, one can see that the question of classroom interaction patterns and practices would appear to impact significantly on the endeavour. Problems 1, 2, 4, 5 and 6 all revolve around questions of interaction - from the perspectives of teacher-student exchange; student participation; classroom dynamics; engagement and motivation, giving rise to the idea that cooperative and collaborative learning, posited as the most determinant and identifiable element of CLIL teaching since its inception (Papaja, 2011; Pavesi et al., 2001), may be largely absent. An over-dependence on conventional, teacher-fronted lecturing seemed to be a key obstacle, an issue that needed to be taken into account in the survey design. Combining Pavesi et al.'s (2001) hypothesis with the main obstacles highlighted in Contero's study (2017) in order to shape the ideal didactic style of a CLIL lecturer, culminated in four main perceptions described as follows:

- Owing to the interactive and cooperative nature of CLIL, students gain self-esteem and self-confidence, and learn to work independently and be more organised.

- My university teaching systematically contemplates interaction and cooperative work in the classroom.

- My responsibility as a faculty member includes fostering my students' selfesteem and self-confidence.

- My lesson planning promotes autonomy as well as developing organisational skills.

- In CLIL it is very important to make extensive use of cooperative and investigative activities, since students need natural opportunities to use the foreign language.

- Interaction both between my students and between students and myself plays a central role in my teaching / work.

- My CLIL teaching at university always encourages student oral and/or written production. 
- Students value the opportunity to use the FL for authentic communication, focusing more on meaning and interaction than on structures and errors.

- I promote spontaneous use of the FL in all my classes, without penalising or judging any misuse or errors that may occur.

- There is interaction in the L2 with the teacher and the other students. This way, students can put their linguistic knowledge into practice and are obliged to expand their communicative resources so that they are able to respond to specific demands of the contents they are working on.

- I usually propose didactic strategies which address the linguistic abilities necessary to deal with the concepts in the subject I teach.

This was supplemented by the following issues addressed by Contero (2017), even though they did not directly correspond to any of the sections proposed by Pavesi et al. (2001):

- CLIL teaching at university level requires coherent planning for each topic.

- My materials are designed from authentic resources in the FL.

- My teaching is planned with attention to possible language learning on the part of students (designing linguistic scaffolding).

- I intentionally include motivational techniques to ensure students take an active role.

- CLIL lecturers have to go through the discovery of teaching formulas that place interaction at the centre of their day to day teaching, which means giving up their traditional role as commentator and indisputable expert of the subject. Thus, they must be aware of their own didactic style.

- I am aware that the degree of satisfaction I have obtained as a teacher in L1 may be different from that which I have in the FL.

In addition, the questionnaire incorporates fact-finding around the following concerns:

- The source of didactic resources used by lecturers whilst planning their CLIL teaching: Internet, specialized bibliographies and others.

- Usual working formula for this didactic design, namely: translation, adaptation or new elaboration.

- The time teachers invest in lesson preparation.

- Promotion of individuality or teamwork: consulting linguistic advisors or other specialists whilst designing sessions.

- Previous consideration of possible linguistic development in the classroom: analysing specific terminology.

- Possible strategies for the promotion of interaction in the classroom: fostering the use of certain types of activities. 
The final version of the survey was drafted at the end of June 2017 and piloted with 20 lecturers, all of whom were enrolled in specific innovation projects for bilingual teaching at the University of Cádiz. After correcting the linguistically complex formulation of some questions, the survey was officially launched on September 7 to a total of 374 CLIL teachers from Andalusian universities. The final version included 15 questions (see Table 1, below) divided into three sections: the general teacher profile of the respondent, the definition of their didactic style as a CLIL teacher and their own assessment of the aforementioned style.

Once the survey had been launched, the URL link was sent to several researchers participating in the AGCEPESA project. They were selected due to their specific knowledge of areas or degrees at Andalusian universities where bilingual teaching is being delivered. These colleagues know the extent to which bilingual or plurilingual experiences or programmes are implemented at every institution. The data gathering process took four weeks and no reminders were sent to increase participant response rate.

\section{Table 1. Questionnaire Items}

AREA 1: TEACHER PROFILE

Demographics and general teaching profile:

1. Gender.

2. Age.

3. Years of teaching experience at university.

4. Professional category at university.

5. Public Andalusian university.

6. Field of knowledge.

7. Subjects you usually teach.

8. FL you use to teach that/those subject(s).

9. Time you have been teaching in a FL.

10. In order to teach in a FL, do you translate the didactic resources from L1 to FL?

11.Subject you teach in a FL (the one you will be referring to in the next questions).

AREA 2: DIDACTIC STYLE

12. Didactic style of the respondent: Evaluate your level of satisfaction with your own teaching:

a) My teaching perfectly fulfils the role assigned to me by society.

b) I am fully satisfied with my teaching.

c) The results of my teaching are very positive. 
13. Regarding the results of teaching per se (not the satisfaction that these could cause), we asked the respondents to value them in relation to the following statements:

a) I am able to attend to the learning needs of my students regarding content and language.

b) The results of my students show that, after my classes, they have improved both language and content skills.

c) I am able to make my students more participative, active and motivated.

AREA 3: SELF ASSESSMENT OF THE AFOREMENTIONED STYLE

14. My lesson planning includes the following elements:

a) Fostering the self-esteem and self-confidence of my students.

b) Promoting the organisational capacities and independent work of my students.

c) Daily interaction between my students and/or myself plays a central role and is replacing the traditional one-way theoretical exposition (teacher-centred lecturing).

d) My classrooms include systematic cooperative work.

15. For the classes I teach in a foreign language, my lesson planning includes the following elements:

a) Oral and/or written production by students.

b) The spontaneous use of the foreign language, without penalising or judging any faults that may occur.

c) Didactic strategies of a linguistic nature to deal with the concepts of the subject I teach.

d) The conscious use of humour as a motivating technique

\section{RESULTS AND DISCUSSION}

A total of 138 lecturers responded to the online questionnaire out of a total of 374 who were invited, yielding a response rate of $36.89 \%$. With regard to gender, $59.4 \%$ were men and $40.6 \%$ women and the average age was 46.2. Table 2 summarizes participant demographic and professional characteristics. Regarding the question of status, we should point out that the Spanish system involves a rather complicated hierarchy ranging from Catedratico, which is the same as 'professor' in English, through various degrees of full-time permanent positions 
Candela C., Francisco Z. and José Luis Arco T. Addressing CliL Lecturers' Needs: Reflections

(titular, doctor contratado etc) to part-time posts such as collaborador(a). According to the data, the prototypical profile of a CLIL university teacher is male, around 46 years old, a "profesor titular" (which implies someone who is a civil servant, similar to the idea of tenure), who has been teaching for more than 14 years at the university, 3.5 of them as a CLIL teacher in/through English.

Table 2. CLIL teacher profiles in Andalusian universities

\begin{tabular}{|c|c|c|c|c|c|}
\hline \multicolumn{6}{|c|}{ PERSONAL DATA } \\
\hline GENDER & $\mathrm{N}$ & PERCENTAGE & AGE & $\mathrm{N}$ & PERCENTAGE \\
\hline Male & 82 & $59.4 \%$ & $21-30$ & 2 & $1.4 \%$ \\
\hline Female & 56 & $40.6 \%$ & $31-40$ & 23 & $16.6 \%$ \\
\hline & & & $41-50$ & 73 & $52.8 \%$ \\
\hline & & & $51-60$ & 37 & $26.8 \%$ \\
\hline & & & $61-70$ & 3 & $2.1 \%$ \\
\hline \multicolumn{6}{|c|}{ PROFESSIONAL DATA } \\
\hline STATUS & $\mathrm{N}$ & PERCENTAGE & $\begin{array}{c}\text { TEACHING } \\
\text { EXPERIENCE }\end{array}$ & $\mathrm{N}$ & PERCENTAGE \\
\hline Catedrático & 18 & $13 \%$ & $\begin{array}{l}\text { Less than } 5 \\
\text { years }\end{array}$ & 6 & $4.3 \%$ \\
\hline Titular & 56 & $40.6 \%$ & 5 to 10 years & 19 & $13.8 \%$ \\
\hline Contratado Dr. & 31 & $22.5 \%$ & 10 to 15 years & 27 & $19.6 \%$ \\
\hline Ayudante Dr. & 14 & $10.1 \%$ & $\begin{array}{l}\text { More than } 15 \\
\text { years }\end{array}$ & 86 & $62.3 \%$ \\
\hline Sustituto & 8 & $5.8 \%$ & & & \\
\hline Colaborador & 5 & $3.6 \%$ & & & \\
\hline Other & 6 & $4.3 \%$ & & & \\
\hline \multicolumn{6}{|c|}{ CLIL DATA } \\
\hline EXPERIENCE & $\mathrm{N}$ & PERCENTAGE & LANGUAGE & $\mathrm{N}$ & PERCENTAGE \\
\hline $\begin{array}{l}\text { Less than } 1 \\
\text { year }\end{array}$ & 8 & $5.8 \%$ & English & 130 & $92.4 \%$ \\
\hline 1 to 3 years & 65 & $47.1 \%$ & French & 6 & $4.3 \%$ \\
\hline 4 to 6 years & 48 & $34.8 \%$ & German & 1 & $0.7 \%$ \\
\hline $\begin{array}{l}\text { More than } 6 \\
\text { years }\end{array}$ & 17 & $12.3 \%$ & Other & 1 & $0.7 \%$ \\
\hline
\end{tabular}


The 138 responses were provided by teachers from 66 different areas, therefore representing a wide variety of subjects. They can be grouped into 14 fields of science and technology as defined by the UNESCO nomenclature to more accurately show which disciplines Andalusian CLIL teachers work in. Table 3 shows how our sample is distributed among these UNESCO fields of classification. It reveals that more than $70 \%$ of Andalusian CLIL lecturing is concentrated in just 4 of these scientific fields, namely: Economy, Education, Engineering and Psychology. Some other fields worth mentioning are International Law, Arts and Chemistry, which collectively represent almost $15 \%$ of university CLIL teaching in Andalusia.

Table 3. Andalusian CLIL university teachers distributed by UNESCO Fields of Science and Technology

\begin{tabular}{|c|c|c|c|}
\hline UNESCO FIELD & $\begin{array}{l}\text { DIFFERENT AREAS WITHIN THE } \\
\text { FIELD }\end{array}$ & TEACHERS & $\begin{array}{l}\text { PERCENT- } \\
\text { AGE }\end{array}$ \\
\hline Agricultural Sciences & $1-($ Vegetal production $)$ & 1 & $0.72 \%$ \\
\hline Arts and Humanities & $5-($ Fine arts theory, Architecture...) & 6 & $4.34 \%$ \\
\hline Chemistry & $\begin{array}{l}2 \text { - (Analytical chemistry, Organic } \\
\text { chemistry) }\end{array}$ & 6 & $4.34 \%$ \\
\hline Economic Sciences & $\begin{array}{l}6-(\text { Economic systems, Economic } \\
\text { accounting, Organization and } \\
\text { management of enterprises, } \\
\text { Economic activity, Econometrics...) }\end{array}$ & 40 & $28.98 \%$ \\
\hline History & $1-($ Ancient history $)$ & 1 & $0.72 \%$ \\
\hline Juridical Science and Law & $\begin{array}{l}4-(\text { International law, National law } \\
\text { and legislation...) }\end{array}$ & 7 & $5.07 \%$ \\
\hline Life Sciences & $\begin{array}{l}4-\text { (Zoology, Botany, Biochemistry } \\
\text { and Molecular biology) }\end{array}$ & 5 & $3.62 \%$ \\
\hline Linguistics & $\begin{array}{l}3-(\text { Classical philology, Linguistic } \\
\text { theory...) }\end{array}$ & 3 & $2.17 \%$ \\
\hline Mathematics & $\begin{array}{l}3 \text { - (Algebra, Geometry, Topology, } \\
\text { Statistics) }\end{array}$ & 3 & $2.17 \%$ \\
\hline Medical Sciences & $\begin{array}{l}5 \text { - (Clinical sciences, Pharmacology, } \\
\text { Pharmacodynamics...) }\end{array}$ & 5 & $3.62 \%$ \\
\hline Pedagogy & $\begin{array}{l}11-(\text { Educational theory and } \\
\text { methods, Teacher training, Education, } \\
\text { organization and planning...) }\end{array}$ & 25 & $18.11 \%$ \\
\hline Physics & $\begin{array}{l}3-\text { (Physics, Applied physics, } \\
\text { Theoretical physics) }\end{array}$ & 3 & $2.17 \%$ \\
\hline Psychology & $\begin{array}{l}5-(\text { Adolescent and child } \\
\text { psychology, Experimental } \\
\text { psychology, General psychology...) }\end{array}$ & 11 & $7.97 \%$ \\
\hline Technological Sciences & $\begin{array}{l}12-(\text { Computer technology, Chemical } \\
\text { engineering, Electronic technology...) }\end{array}$ & 22 & $15.94 \%$ \\
\hline
\end{tabular}


All CLIL subjects taught in French or German (5.4\% of the data) belong to the field of Pedagogy, whereas English is the one and only FL used for teaching in the other three main scientific fields highlighted in Table 3.

When comparing this data with that referring to teaching styles, some other interesting findings can be presented:

Firstly, having been asked about the way they plan and prepare their classes, around half of the Andalusian CLIL lecturers in our study (47\%) confessed to translating their materials directly into English from the didactic resources they regularly use in Spanish, whereas 53\% defended the idea of designing them specifically for their CLIL teaching using original L2 resources. These results match Contero's findings (2017). What we can observe now is a direct link between the trend to translate or not from Spanish with the number of years of CLIL experience obtained. Lecturers who always translate materials from L1 into L2 (12\%) have an average of little more than 2 years of CLIL experience; in contrast, lecturers who do not always do this (35\%) have more than 3 years of CLIL experience; and lecturers who refuse to translate at all $(53 \%)$ have at least almost 4 years of CLIL teaching experience. This implies a direct correlation between practical CLIL experience and the confidence/ ability to design original materials.

Secondly, more than $85 \%$ of lecturers feel generally satisfied or very satisfied with their teaching activity, stating that the social function of this work is the most highly valued feature for them. The remaining $15 \%$ are more critical of their work. Interestingly, $50 \%$ of these critical lecturers belong to the group who actively refuse to translate didactic materials, that is to say, the most experienced group of teachers. That said, there also appears to be an age factor since this critical attitude is mostly maintained by younger lecturers (up to 44 years old), whereas the ones who are generally satisfied have an average age of over 45 .

This initial critical attitude towards their own teaching activity increases up to $17.6 \%$ among lecturers when asked about their ability to design lessons where both language and content are treated in an equal way. And this concern is confirmed when the question refers to the results of this balanced teaching, where more than $40 \%$ of lecturers are less satisfied.

Additionally, over $33 \%$ of lecturers recognise that they do not keep their students actively motivated and engaged. When asked about possible teaching procedure reasons for this, the following answers (table 4) emerge:

Table 4. Andalusian CLIL University Teachers Teaching Style

\begin{tabular}{|l|c|c|}
\hline DO YOU PLAN YOUR LESSONS CONSIDERING... & YES & NO \\
\hline Your students' self-confidence? & $70.76 \%$ & $29.23 \%$ \\
\hline Organizational skills for independent work? & $80.76 \%$ & $19.23 \%$ \\
\hline Interaction as basic for learning? & $72.30 \%$ & $27.69 \%$ \\
\hline Tasks where systematic cooperation is required? & $63.07 \%$ & $\mathbf{3 6 . 9 2 \%}$ \\
\hline Linguistic scaffolding? & $38.46 \%$ & $\mathbf{6 1 . 5 3 \%}$ \\
\hline Spontaneous and open intervention by students? & $92.30 \%$ & $7.69 \%$ \\
\hline Oral and written use of language? & $72.30 \%$ & $27.69 \%$ \\
\hline Entertaining moments (or materials) for motivation? & $54.61 \%$ & $\mathbf{4 5 . 3 8 \%}$ \\
\hline
\end{tabular}


A close look at data lets us observe that linguistic scaffolding appears to continue to be the biggest obstacle for a high percentage of lecturers. A possible reason for this, apart from the stated fact that most lecturers require more and more focused methodological training, may be that the majority of them work with no assistance or advice from a foreign language teacher.

In addition to this, numerous elements in regular classes and cooperative tasks can be improved by CLIL lecturers at Andalusian universities. One area commonly identified is academic rigour displayed by serious talk or debate, since generating intentional motivation continues to be seen as a rather childish issue (Contero, 2016) that lecturers prefer to avoid for a more scientific approach.

Returning to the research questions posed at the outset, the findings here obtained suggest the following:

1. Regarding the typical professional profile of a plurilingual university teacher: Andalusian CLIL lecturers tend to be male tenured lecturers in their forties with more than 15-years teaching experience. They have mostly been teaching through CLIL for 1 to 3 years using English as their FL. It would be interesting to compare this profile with data regarding university lecturers in general - for example, to discover whether men dominate in the profession overall; but this data does not seem to be publicly available.

2. Relating to the question of scientific fields; economic sciences followed by Pedagogy/Didactics as well as Technological sciences are the UNESCO fields within which most (current) Andalusian CLIL lecturers are working. It remains to be seen whether this will remain constant as integrated content and language approaches continue to spread.

3. From the perspective of methodological intricacies clearly identified by lecturers along with linguistic ones, perhaps the most striking comment lecturers make regarding their teaching difficulties seems to revolve around the question of the identification and implementation of language scaffolding techniques. This suggests that CLIL lecturers are aware of the importance of considering language in their lesson planning, but they appear to have problems in identifying possible procedures for managing L2 integration through scaffolding strategies (on this question see also the articles by Rubio Cuenca and Moore, and Sánchez-García in this volume).

4. Considering the relationship between teaching styles and methodological and/or linguistic variables, and their potential effect on university CLIL teaching styles; five particular methodological and linguistic variables, previously identified in Contero's research (2017), have been confirmed in the present study, leading to the proposition that proposals for more effective methodological training should pay special attention to these needs: 
- Area 1. Participants' roles and settings, where interaction, cooperation and autonomy can be considered as tools for teaching activities.

- Area 2. Scaffolding models, where teachers learn how to attend to their students' linguistic needs regarding the content they will be dealing with.

- Area 3. Sequence planning, where control over the available time and space for CLIL teaching is essential.

- Area 4. Linguistic awareness, where specific communicative consequences of integrating FL in a content class can be considered.

- Area 5. Authenticity, not just related to cases and examples that students could be working on but also to the L2 materials and resources themselves.

\section{Conclusions}

While we note an increasing abundance of research papers on this emergent subdiscipline (Arco-Tirado, Fernández-Martin \& Hernández-Moreno, 2016) including impact evaluation studies (e.g., Arco-Tirado, et al., 2018), we need to bear in mind that we are focusing on a didactic proposal which, particularly in university settings, is still under construction, indeed, arguably still in an initial phase of development and research.

It seems safe to suppose that research can and will pinpoint problematic areas in CLIL university teaching and will contribute to reflect on them in a practical and constructive way. Starting from the assumption already identified by several experts (Mehisto et al., 2008 and Pavón \& Gaustad, 2013) that certain methodological aspects need to be included in bilingual teacher development activities designed for lecturers, the results from this study fully align with those already found by Contero (2017) and Zayas \& Contero (2012).

This study aimed to identify methodological needs of lecturers from all over the region when teaching in bilingual or plurilingual programmes. In doing so, the scope of previous work in the field was widened to obtain a broader perspective of how the integration of content and foreign languages is being implemented and how this appears to be related to and affected by lecturer didactic styles.

One of the most significant findings to emerge from this study is that the more years lecturers have been involved in CLIL teaching, the more convinced they are that new and purposeful didactic materials should be designed for teaching in a FL, rather than translating from material used to teach in L1. In other words, gaining experience in integrating content and language in Higher Education reassures the teacher of the need for adaptation rather than translation from L1 to L2. In turn this suggests that perhaps the question of materials design/adaptation should feature more in on-going development than in initial, introductory programmes.

Lecturers' concerns regarding linguistic awareness and scaffolding in CLIL teaching were also revealed as they acknowledged their considerable doubts as to whether they were covering the language skills necessary when integrating the FL into their content sessions. Since these are content teachers, coming from subject specialisations which have traditionally been regarded as 'non-linguistic', we should not be surprised at this uncertainty, but we clearly need to address it in teacher development. 
Strengthening student motivation was another key finding in our study, as we observed that a high percentage of respondents did not feel that their students were sufficiently motivated and engaged in the learning process. This may be related to the question of providing opportunities for authentic information exchange and debate. Although, of course, we did not enquire into perceived motivation levels in L1 teaching and so we do not know if this is a specifically CLIL-related problem.

Teacher development courses that specifically address CLIL lecturers' needs should, therefore, cover major methodological areas such as interaction, cooperation, student autonomy, linguistic awareness and scaffolding, as well as convincing lecturers to generate an authentic CLIL environment in class.

\section{REFERENCES}

Arco-Tirado, J.L., Fernández-Martín, F.D., \& Hernandez-Moreno, N. (2016). Skills learning through a bilingual mentors program in higher education. International Journal of Bilingual Education and Bilingualism. Advance online publication. doi:10.1080/13670050.2016.1228601.

Arco-Tirado, J. L., Fernández-Martín, F. D., Ramos-García, A. M., Littvay, L., Villoria, J., \& Naranjo, J. A. (2018). A Counterfactual Impact Evaluation of a Bilingual Program on Students' Grade Point Average at a Spanish University. Evaluation and Program Planning. 68, 81-89. Available at https://doi.org/10.1016/j.evalprogplan.2018.02.013

Cenoz, J. \& Etxague, X. (2013). From Bilingualism to Multilingualism: Basque, Spanish and English in Higher Education, in C. Abello-Contesse, P.M. Chandler, M.D. López-Jiménez, \& R. Chacón-Beltrán (Eds.), Bilingual and Multilingual Education in the 21st Century: Building on Experience (pp. 85-106). Bristol: Multilingual Matters.

Contero, C. (in press). The Key Role of Foreign Language teachers in Content and Language Integrated Learning at University. International Journal of Learning in Higher Education (Online).

Contero, C. (2017). Técnicas didácticas y metodológicas para el perfeccionamiento de la gestión del aprendizaje del profesor AICLE en la enseñanza superior (Unpublished PhD. dissertation). University of Cadiz, Spain.

Contero, C. (2016). El valor del elemento lúdico en la enseñanza AICLE universitaria, in A. Díez Mediavilla, V. Brotons Rico, D. Escandell \& J. Rovira-Collado (Eds.), Aprendizajes plurilingües y literarios. Nuevos enfoques didácticos (pp. 85-91). Alacant: Publicacions de la Universitat d'Alacant.

Conferencia de Rectores de las Universidades Españolas (2007). Código de universidades. BOE. 1127.

Doiz, A., Lasagabaster, D. \& Sierra, J.M. (2013). English-Medium Instruction at Universities. Global Challenges. Bristol: Multilingual Matters.

Ellison, M., Aráujo, S., Correia, M., \& Vieira, F. (2017). Teachers' perceptions of need in EAP and ICLHE contexts, in J. Valcke \& R. Wilkinson (Eds.), Integrating Content and Language in Higher Education. Perspectives on Professional Practice (pp. 59-76). Frankfurt a.M.: Peter Lang. 
Candela C., Francisco Z. and José Luis Arco T. Addressing CliL Lecturers' Needs: Reflections

Estrada, J.L. (2017). Tratamiento de errores en la enseñanza de lenguas extranjeras en la educación superior: posibilidades de corrección no intervencionista en la producción oral (Unpublished PhD. Dissertation). University of Cadiz.

Järvinen, H.M. (Ed.) (2009). Handbook: Language in Content Instruction. Turku, University of Turku: Socrates Education and Culture.

Martínez, R. (1995). El método de encuestas por muestreo: Conceptos básicos, in M.T. Anguera, J. Arnau, M. Ato, T. Martínez, J. Pascual, \& G. Vallejo (Eds.), Métodos de investigación en Psicología, (pp. 385-432). Madrid, Spain: Síntesis.

Mehisto, P., Marsh, D., \& Frigols, M.J. (2008). Uncovering CLIL. London: Macmillan.

Marsh, D. (1994). Bilingual Education \& Content and Language Integrated Learning. Paris: University of Sorbonne, International Association for Cross-cultural Communication, Language Teaching in the Member States of the European Union (Lingua).

Papaja, K. (2011). Analyzing Types of Classroom Interaction in CLIL, available from: http://pressto. amu.edu.pl/index.php/gl/article/viewFile/333/240 , accessed 21 October, 2017.

Pavesi, M., Bertocchi, D., Hofmannová, M. \& Kazianka, M. (2001). Enseñar en una lengua extranjera. Cómo utilizar lenguas extranjeras en la enseñanza de una asignatura. TIE CLIL (Translanguage in Europe - Content and Language Integrated Learning), available from: http://www.ub.edu/filoan/CLIL/profesores.pdf accessed 18 February, 2018.

Pavón, V. \& Gaustad, M. (2013). Designing Bilingual Programmes for Higher Education in Spain: Organisational, Curricular and Methodological Decisions. International CLIL Research Journal, 2(1), 82-94.

Pérez Cañado, M.L. (Ed.) (2013). Competency-based Language Teaching in Higher Education. London: Springer.

Romero, E. \& Zayas, F. (2017). Challenges and opportunities of training teachers for plurilingual education, in J. Valcke \& R. Wilkinson (Eds.) Integrating Content and Language in Higher Education. Perspectives on Professional Practice (pp. 205-225). Frankfurt a.M.: Peter Lang.

Smit, U. \& Dafouz, E. (2012). Integrating content and language in higher education. An introduction to English-medium policies, conceptual issues and research practices across Europe, in U. Smit \& E. Dafouz (Eds.) Integrating Content and Language in Higher Education. Gaining Insights into English-Medium Instruction at European Universities (pp. 1-12). Special Issue of AILA Review 25.

Van Leeuwen, C. \& Wilkinson, R., (Eds.) (2003). Multilingual approaches in university education. Maastricht: Universiteit Maastricht/Uitgeverij Valkhof Pers.

Zayas, F. \& Contero, C. (2012). Tutorización de profesores AICLE en la Universidad: una propuesta para enfrentarse al cambio, in TRICLIL: II International Round Table on CLIL Programmes (pp. 306-309). Barcelona: Universitat Autònoma de Barcelona. 